Article

\title{
Vancomycin-Loaded Furriness Amino Magnetic Nanospheres for Rapid Detection of Gram-Positive Water Bacterial Contamination
}

\author{
Ahmed M. Azzam 1,2 ${ }^{\mathbb{D}}$, Mohamed A. Shenashen 1,3,*, Mohamed S. Selim ${ }^{1,3}$, Bayaumy Mostafa ${ }^{2}$, Ahmed Tawfik 4 \\ and Sherif A. El-Safty ${ }^{1, *}$ \\ 1 National Institute for Materials Science (NIMS), 1-2-1 Sengen, Tsukuba-shi 305-0047, Ibaraki-ken, Japan; \\ ah.azzam@tbri.gov.eg (A.M.A.); moh.selim_chem2006@yahoo.com (M.S.S.) \\ 2 Environmental Research Department, Theodor Bilharz Research Institute (TBRI), Imbaba, Giza 12411, Egypt; \\ bbmostafa@outlook.com \\ 3 Egyptian Petroleum Research Institute (EPRI), Nasr City, Cairo 11727, Egypt \\ 4 Water Pollution Research Department, National Research Centre (NRC), Dokki, Giza 12622, Egypt; \\ prof.tawfik.nrc@gmail.com \\ * Correspondence: SHENASHEN.Mohameda@nims.go.jp (M.A.S.); Sherif.ELSAFTY@nims.go.jp (S.A.E.-S.)
}

check for

updates

Citation: Azzam, A.M.; Shenashen,

M.A.; Selim, M.S.; Mostafa, B.; Tawfik,

A.; El-Safty, S.A. Vancomycin-Loaded

Furriness Amino Magnetic

Nanospheres for Rapid Detection of

Gram-Positive Water Bacterial

Contamination. Nanomaterials 2022,

12, 510. https://doi.org/10.3390/

nano12030510

Academic Editors: Miguel Gama and Witold Łojkowski

Received: 23 December 2021

Accepted: 27 January 2022

Published: 1 February 2022

Publisher's Note: MDPI stays neutral with regard to jurisdictional claims in published maps and institutional affiliations.

Copyright: () 2022 by the authors Licensee MDPI, Basel, Switzerland. This article is an open access article distributed under the terms and conditions of the Creative Commons Attribution (CC BY) license (https:// creativecommons.org/licenses/by/ $4.0 /)$.

\begin{abstract}
Bacterial pathogens pose high threat to public health worldwide. Different types of nanomaterials have been synthesized for the rapid detection and elimination of pathogens from environmental samples. However, the selectivity of these materials remains challenging, because target bacterial pathogens commonly exist in complex samples at ultralow concentrations. In this study, we fabricated novel furry amino magnetic poly-L-ornithine (PLO)/amine-poly(ethylene glycol) (PEG)-COOH/vancomycin (VCM) (AM-PPV) nanospheres with high-loading VCM for vehicle tracking and the highly efficient capture of pathogens. The magnetic core was coated with organosilica and functionalized with cilia. The core consisted of PEG/PLO loaded with VCM conjugated to Gram-positive bacterial cell membranes, forming hydrogen bonds with terminal peptides. The characterization of AM-PPV nanospheres revealed an average particle size of $56 \mathrm{~nm}$. The fieldemission scanning electron microscopy (FE-SEM) micrographs showed well-controlled spherical AM-PPV nanospheres with an average size of $56 \mathrm{~nm}$. The nanospheres were relatively rough and contained an additional $12.4 \mathrm{~nm}$ hydrodynamic layer of PLO/PEG/VCM, which provided additional stability in the suspension. The furry AM-PPV nanospheres exhibited a significant capture efficiency $(>90 \%)$ and a high selectivity for detecting Bacillus cereus (employed as a model for Gram-positive bacteria) within $15 \mathrm{~min}$, even in the presence of other biocompatible pathogens. Moreover, AM-PPV nanospheres rapidly and accurately detected B. cereus at levels less than $10 \mathrm{CFU} / \mathrm{mL}$. The furry nano-design can potentially satisfy the increasing demand for the rapid and sensitive detection of pathogens in clinical and environmental samples.
\end{abstract}

Keywords: magnetic nanospheres; bacterial pollution; detection; vancomycin

\section{Introduction}

Pathogenic bacteria cause environmental contamination and serious diseases and have become a significant public health burden over time [1]. These pathogens responsible for many diseases, such as septicemia, meningitis, gastroenteritis, and abortion, which are all associated with a high mortality rate [2]. Bacillus cereus (B. cereus) is one of the most prevalent human pathogens in the environment, and it is a foodborne spore-forming bacterium causing food poisoning. B. cereus can cause many gastrointestinal disorders such as vomiting and diarrhea due to toxins production [3]. The development of a rapid, sensitive, and selective method for pathogen detection is vital to improve the treatment of diseases [4]. Many studies have investigated the rapid and highly selective detection 
of bacterial pathogens. However, highly accurate and satisfactory culture-based assays without pre-enrichment have not been established yet for detecting bacteria at ultralow concentrations in clinical or environmental specimens. Existing detection methods require a considerable amount of time [5]. Samples should be concentrated by minimizing the samples volumes for the rapid and dependent capture of pathogenic bacteria [6]. Immunological methods with antigen-antibody reaction have also been widely used in pathogen detection but require specific antibodies and complex technicians. Nucleic acid amplification-based methods show the potential for bacterial classification. PCR is a precise method which is able to detect one bacterium, but in case of pure DNA in complex environmental samples, it cannot guarantee satisfactory specificity. Methods for the rapid, specific, and sensitive detection of bacteria remain an interesting research topic, because the bacterial environment is excessively complex; moreover, the present purified techniques take a very long time and have a minimum reproductive rate $[7,8]$. Nanotechnology beats all these problems and implements a direct detection of target bacteria in complex environments in a short time. Many studies concerning nanotechnology-based biosensors showed promising outcomes for biological compounds and pathogenic agents based on silica, alumina, carbon nanotubes, magnesium hydroxide, silver, magnetic, and mesoporous nanomaterials [9-15].

The bio-application of magnetic iron oxide nanoparticles in the analysis field was recently demonstrated due to their attractive impacts, high loading capacity, and ease of effective modification [16-19]. For example, magnetic nanoparticles (MNPs) are used as a carrier for purification/separation [20]. Jo et al. used nano-MNPs for catching free cancer cells [21]. Kuo et al. [22] reported biofunctional MNPs for pathogen separation and concentration. MNPs are also utilized for purifying target bacteria and increasing their count to allow the easy bacterial identification [23].

Iron MNPs are functionalized with certain molecules, such as amine groups [24], antibodies [25], bacteriophages [26], nucleic acids [8], or peptides [22], for capturing bacterial cells. These functional groups can improve the sensitivity of pathogen detection based on the pre-enrichment of MNPs but exhibit limitations, such as high cost, low stability, and low selectivity, which impedes their application in the diagnosis of bacterial pathogens. Small, highly stable, and low-cost particles could be an attractive alternative to MNPs [27]. Broad-spectrum antibiotics are standard particles due to their high binding capacities to target bacterial cell membranes [28].

In this work, we reported novel fabricated furry multivalent amino magnetic core/ organically functionalized multi-shells of poly-L-ornithine (PLO)/amine-poly(ethylene glycol) (PEG)-COOH/vancomycin (VCM) nanospheres (AM-PPV NSs) for the highly selective diagnosis and rapid separation of Gram-positive bacteria in complex environmental and clinical samples, as shown in Scheme 1. PLO works as a linker between AM-NSs and VCM due to the presence of the amine group and improves the high loading capacity of the latter to provide multiple active sites. Thus, this orientation of AM-PPV NSs can satisfy the increasing demand for rapid pathogen diagnosis due to the following:

(I) The VCM corona on MNPs provides many active sites for the high selectivity of Gram-positive bacteria in mixed specimens;

(II) The PLO and PEG polymers on AM-NSs provide elastic cilia, excellent scattering, and improved VCM enrichment efficiency; and

(III) High concentrations of VCM on the AM shell qualify NSs to effectively attach to the target bacterial cell membrane.

The capacity and selectivity of NSs for B. cereus (employed as a model) were assayed to evaluate the feasibility of furry AM-PPV NSs. B. cereus is a rod-like Gram-positive bacterium that is prevalent in the environment. B. cereus is the main cause of food poisoning and other dangerous and fatal infections in the gastrointestinal tract [29]. The detection limit of AM-PPV NSs against B. cereus was determined. Moreover, the removal capacity and selectivity of the developed materials were tested. The fabricated furry magnetic NSs exhibited an efficient enrichment and a satisfactory purity and thus can be used to detect pathogens in environmental and clinical samples. 


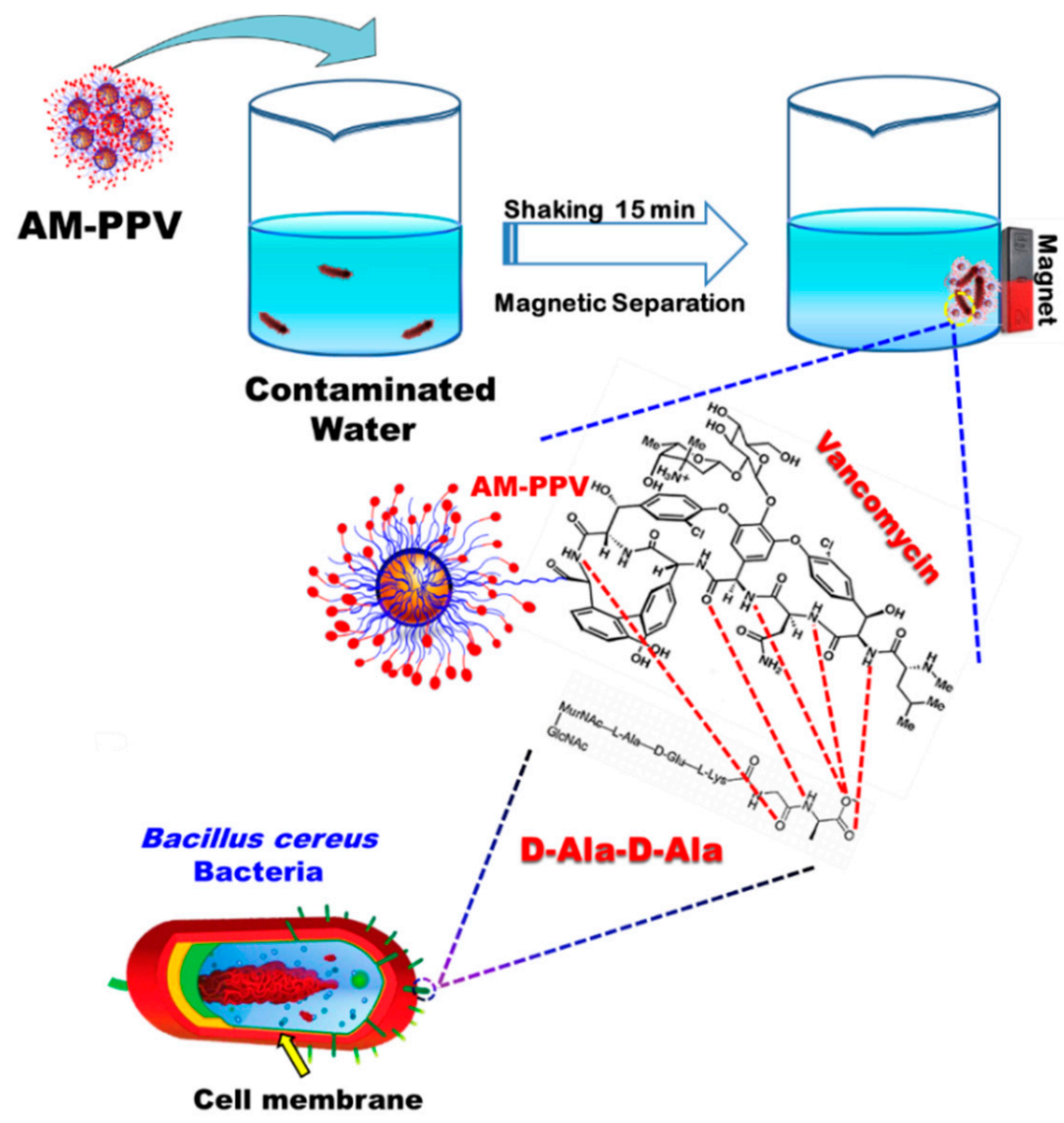

Scheme 1. Capture of bacteria from contaminated water using furry amino magnetic poly-L-ornithine (PLO)/poly(ethylene glycol) (PEG)/vancomycin (VCM) (AM-PPV) nanospheres (NSs) by magnetic separation, which were conjugated with the terminal (D-alanyl-D-alanine) of the bacterial cell membrane through a five-point hydrogen bonding.

\section{Materials and Methods}

\subsection{Materials and Reagents}

All media and chemicals used in the present study were in analytical grade and used without further purification. 1-(3-dimethylaminopropyl)-3-ethylcarbodiimide hydrochloride (EDC), (3-Aminopropyl)triethoxysilane (APTES), N-hydroxysuccinimide (NHS), VCM hydrochloride, PLO (Mw: 15-30 kDa), amine-poly(ethylene glycol)-carboxymethyl (aminePEG5000-COOH), 2-(N-morpholino) ethanesulfonic acid (MES), $\mathrm{NaCl}, \mathrm{KCl}, \mathrm{Na}_{2} \mathrm{HPO}_{4}$, $\mathrm{KH}_{2} \mathrm{PO}_{4}$, and fluorescence dye Hoechst 33258 were obtained with a $99 \%$ purity from SigmaAldrich (St. Louis, MI, USA). Nutrition media used in the present study were obtained from HiMedia Laboratories Ltd. (Mumbai, India) and the API 20E system (BioMerieux, Marcy-l'Étoile, France). B. cereus, Pseudomonas aeruginosa (P. aeruginosa), Escherichia coli (E. coli), and Klebsiella pneumonia (K. pneumonia) were obtained from Environmental Research Department, Theodor Bilharz Research Institute, Giza, Egypt. All aqueous solutions were prepared by Milli-Q water.

\subsection{Furry AM-PPV NSs Fabrication Steps}

\subsubsection{Synthesis of AM-NSs}

Hydrophilic $\mathrm{Fe}_{3} \mathrm{O}_{4}$ NPs were fabricated by a simple alkaline deposition method [30]. The $\mathrm{Fe}_{3} \mathrm{O}_{4} \mathrm{NSs}$ were synthesized by adding $\mathrm{Fe}^{2+}$ into an alkaline solution at $90^{\circ} \mathrm{C}$ dropwise, in the presence of citrate and sodium nitrate. The obtained black precipitate was washed with water and ethanol several times and then dried at $50^{\circ} \mathrm{C}$. The hydrophilic MNSs were easily dispersed in ethanol and used as seeds in the next step. The formation of the amino 
shell was fabricated by dispersing $0.3 \mathrm{~g}$ of MNSs in $4 \mathrm{~mL}$ DW then and $600 \mathrm{~mL}$ of ethanol $(99.99 \%)$ under sonication for $45 \mathrm{~min}$. After that, 10\% $(v / v)$ APTES in an aqueous solution $(80 \mathrm{~mL})$ and glycerol $(40 \mathrm{~mL})$ were added to the above MNSs solution and stirred for $2 \mathrm{~h}$ in a nitrogen atmosphere at $90{ }^{\circ} \mathrm{C}$. Then, the solution was cooled to room temperature. The NSs were washed with Milli-Q water and ethanol. The prepared AM-NSs were stored in Milli-Q water.

\subsubsection{Synthesis of VCM-PEG}

VCM (30 mg) was mixed with NHS (60 mg) and EDC (80 mg) in $400 \mu \mathrm{L}$ of dimethyl sulfoxide. The mixture was purified by recrystallization in diethyl ether. The purified VCM was stirred with amine polyethylene glycol carboxymethyl (H2N-PEG-COOH) (5.0 kDa, $60 \mathrm{mg}$ ) for $6 \mathrm{~h}$ in an alkaline solution ( $\mathrm{NaOH}, \mathrm{pH}$ 8.0). The VCM-PEG product was collected by ultrafiltration centrifugation (Scheme 2A). The formation of the VCM-PEG molecules was confirmed using UV-VIS spectrometry with a UV-VIS spectrophotometer model, i.e., Solidspec-3700 model (Shimadzu, Kyoto, Japan).
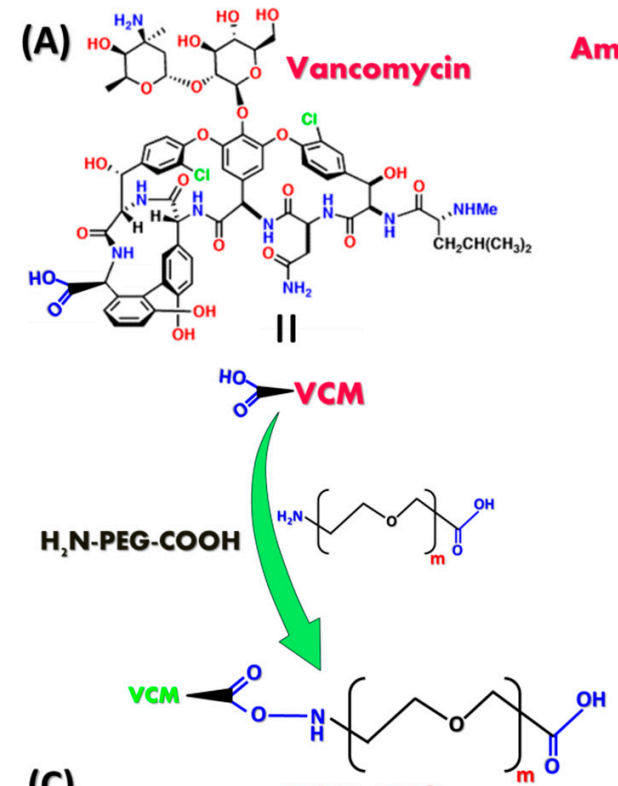

(C)

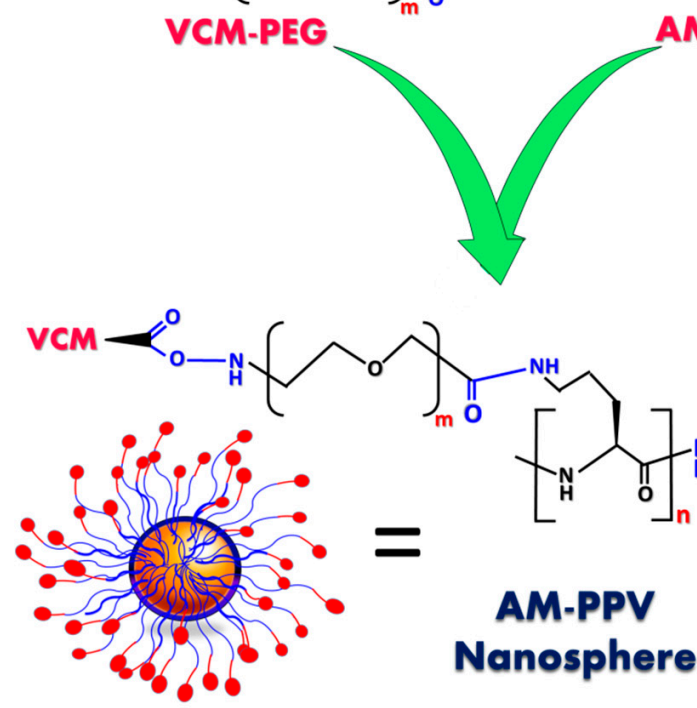

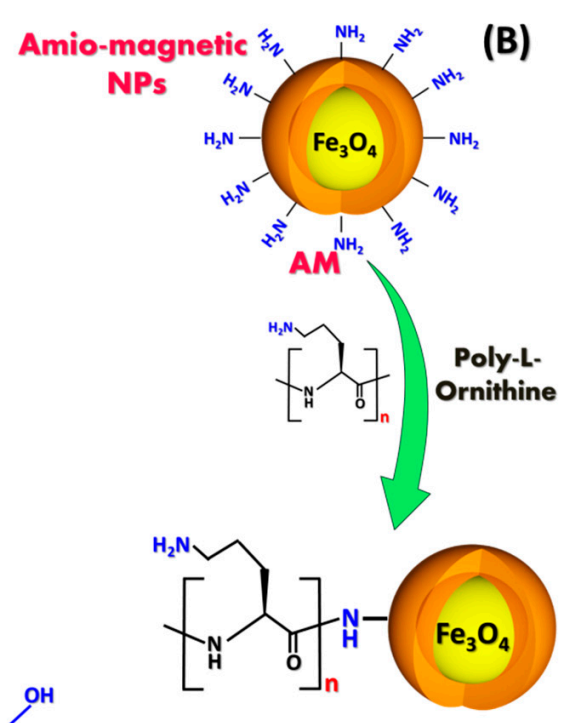

AM-PLO

Scheme 2. Chemistry underlying the furry AM-PPV NS: (A) conjugation of VCM with amine-PEGcarboxymethyl to form VCM-PEG; (B) reaction between the amino magnetic NS with PLO, forming AM-PLO; and (C) building of the furry AM-PPV NS through the carbodiimide chemistry between AM-PLO and VCM-PEG. 


\subsubsection{Synthesis of AM-PLO NSs}

Equal volumes $(400 \mu \mathrm{L})$ of PLO hydrobromide $(50 \mu \mathrm{g} / \mathrm{mL})$ and a $\mathrm{NaOH}$ solution ( $\mathrm{pH}$ 8.0) were mixed at room temperature (RT), and ditert-butyl dicarbonate $(30.6 \mathrm{mg})$ was added to form Boc-N-PLO precipitates, which were collected by centrifugation. AM-NSs $(4 \mathrm{mg})$ were washed with a $\mathrm{NaOH}$ solution $(0.01 \mathrm{M})$ and then mixed with Boc-N-PLO, NHS $(4.4 \mathrm{mg})$, and EDC $(2.2 \mathrm{mg})$ in DMSO $(800 \mu \mathrm{L})$. The AM-PLO-N-Boc was washed several times with saturated $\mathrm{NaCl}$ through magnetic separation. After that, to remove the N-Boc-protecting group, trifluoroacetic acid $(2.0 \mathrm{~mL})$ and methylene chloride $(2.0 \mathrm{~mL})$ were added to functionalized NSs and kept on ice for $60 \mathrm{~min}$ (Scheme 2B).

\subsubsection{Fabrication of Furry AM-PPV NSs}

The fabrication of furry AM-PPV NSs was made by mixing EDC $(6.5 \mathrm{mg})$ and NHS (13 mg) to AM-PLO and PEG-VCM solutions and shaking for $30 \mathrm{~min}$. The AM-PPV NSs were magnetically separated, washed and stored in MES (30 mM, pH 6.0). The fabrication process of furry AM-PPV NSs is shown in Scheme 2C.

\subsection{Structural Characterization of Furry AM-PPV NSs}

The structural features of the AM-PPV NSs were investigated via field-emission scanning electron microscopy (FE-SEM, JEOL model 6500, Tokyo, Japan). Before insertion into the chamber, the AM-PPV NSs powder was ground and fixed onto a specimen stub using a one double-sided carbon tape. Then, a $10 \mathrm{~nm}$ Pt film was coated via anion sputtering (Hitachi E-1030, Tokyo, Japan) at room temperature to obtain high-resolution micrographs. Before sputtering deposition, the $\mathrm{Pt}$ target (4 $\mathrm{nm}$ in diameter; purity: $99.95 \%$ ) was sputtercleaned in pure Ar. The sputtering deposition system used for the experiments consisted of a stainless steel chamber, evacuated down to $8 \times 10^{-5} \mathrm{~Pa}$ with a turbo molecular pump backed up by a rotary pump. The Ar working pressure $\left(2.8 \times 10^{-1} \mathrm{~Pa}\right)$, the power supply $(100 \mathrm{~W})$, and the deposition rate were kept constant throughout these investigations. Moreover, to record the SEM micrographs of the AM-PPV NSs sample better, the scanning electron microscope was operated at $20 \mathrm{keV}$. ED-STEM was carried out at a camera length of $40 \mathrm{~cm}$ and a spot size of $1 \mathrm{~nm}$. In the ED-STEM and FE-SEM characterization, the AM-PPV NSs were dispersed in an ethanol solution using an ultrasonic cleaner and then dropped on a copper grid.

X-ray photoelectron spectroscopy (XPS) was conducted using a PHI Quantera SXM (ULVAC-PHI) (Perkin-Elmer Co., Waltham, MA, USA) with monochromated AlK $\alpha$ radiation $(1.5 \times 0.1 \mathrm{~mm}, 15 \mathrm{kV}, 50 \mathrm{~W})$. Wide-angle powder X-ray diffraction $(\mathrm{XRD})$ patterns were measured using an $18 \mathrm{~kW}$ diffractometer (Bruker D8 Advance, Billerica, MA, USA) with monochromated $\mathrm{CuK} \alpha$ radiation. The sample measurement was repeated three times under rotation at various angles $\left(15^{\circ}, 30^{\circ}\right.$, and $\left.45^{\circ}\right)$. The diffraction data were analyzed using the DIFRAC plus Evaluation Package (EVA) software with the PDF-2 Release 2009 databases provided by Bruker AXS. The standard diffraction data were identified according to the databases of the International Centre for Diffraction Data (ICDD).

\subsection{Bacteria Sample Preparation}

Bacterial pure strains were cultured in a shaker incubator in Luria broth (LB) media at $180 \mathrm{rpm}$ and $37^{\circ} \mathrm{C}$ for $12 \mathrm{~h}$. During the exponential growth phase, the bacterial growth was centrifuged at a high speed, and then, the bacteria were collected and washed by PBS $(0.1 \mathrm{M})$. To form a seed culture suspension, the concentration was adjusted to $\mathrm{OD}_{600}=1$ using a spectrophotometer (Spectronic 20D, Thermo Scientific, Waltham, MA, USA), which was equivalent to the bacterial concentration of $1 \times 10^{8} \mathrm{CFU} / \mathrm{mL}$.

\subsection{Electronic Microscopy Imaging for the Captured B. cereus}

The B. cereus seed culture was washed and resuspended using an autoclaved saline solution $(0.9 \%)$, and $50 \mu \mathrm{L}$ of AM-PPV NSs $(5 \mathrm{mg} / \mathrm{mL})$ were added to the bacterial suspension $\left(1 \mathrm{~mL}, 1 \times 10^{3} \mathrm{CFU} / \mathrm{mL}\right)$ on a shaker for $15 \mathrm{~min}$. After magnetic separation, the conjugated 
B. cereus bacterial cells with AM-PPV NSs were examined using a transmission electron microscope (EM 208S Philips, Amsterdam, The Netherlands) at $80 \mathrm{kV}$ and a scanning electronic microscope (HITACHI S-4800, Tokyo, Japan).

\subsection{B. cereus Fluorescence Imaging}

B. cereus bacterial cells at different concentrations $\left(1 \times 10^{2}-1 \times 10^{8} \mathrm{CFU} / \mathrm{mL}\right)$ were incubated with AM-PPV NSs and AM-VCM $(5 \mathrm{mg} / \mathrm{mL})$ in the presence of the diluted Hoechst 33258 dye for $15 \mathrm{~min}$ at RT under faint light [31]. The attached B. cereus bacterial cells and original solutions were examined and imaged with fluorescence microscopy at $352 \mathrm{~nm}$.

\subsection{The Plate Count Method for the Capture Capacity of AM-PPV NSs}

AM-PPV NSs and AM-VCM NPs were added $(5 \mathrm{mg} / \mathrm{mL})$ to different $B$. cereus concentrations $\left(1 \times 10^{2}-1 \times 10^{8} \mathrm{CFU} / \mathrm{mL}\right)$ to test the capture capacity of AM-PPV NSs against AM-VCM for capturing Gram-positive bacterial cells. After incubation on the shaker for $15 \mathrm{~min}$, the NSs were magnetically separated, and then supernatants solutions were cultivated on nutrient ager plates and incubated at overnight at $37^{\circ} \mathrm{C}$ to detect the capacity of AM-PPV NSs for capturing bacterial cells. The corresponding capture efficiencies were calculated based on the following equation:

$$
\text { Capture efficiency }(\%)=[\mathrm{O}-\mathrm{L}] / \mathrm{O} \times 100,
$$

where $\mathrm{O}$ denotes the number of the original bacteria, and $\mathrm{L}$ indicates the remaining bacterial numbers after the separation from the NS-enriched B. cereus.

\subsection{Specificity of AM-PPV NSs to Gram-Positive Pathogens}

AM-PPV NSs $(5.0 \mathrm{mg} / \mathrm{mL})$ were added to the mixed water sample containing different bacterial species of G-positive (B. cereus) and G-negative ones (P. aeruginosa, E. coli, and K. pneumonia) at a concentration $1 \times 10^{4} \mathrm{CFU} / \mathrm{mL}$ and incubated on a shaker for $15 \mathrm{~min}$. After magnetic separation, AM-PPV NSs were washed three times with PBS, then spread on nutrient ager plates and incubated at overnight at $37^{\circ} \mathrm{C}$. The remaining water sample was cultivated on nutrient agar plates. After incubation, the growths of the conjugated bacterial species and the remaining ones were examined and identified using an Analytical Profile Index (API) 20E system.

\section{Results and Discussion}

\subsection{Strategy Mechanism of the Furry NS-High-Loading VCM}

Recently, more simple, sensitive, and cost-effective methods were progressed for the detection of pathogens [32-34]. In addition, highly sensitive and inexpensive techniques have been developed for bacterial capture [1,35]. Moreover, the outcomes are constantly unsatisfactory, primarily because pathogens commonly exist in complex samples in the environment [36]. To avoid this issue, VCM conjugated with magnetic nanoparticles was used for the detection of pathogens [37]. However, due to the poor loading of nanomaterials with VCM, the results remained impractical. In this study, we designed a "furry" ligandfunctionalized AM-NS for the rapid and selective separation of Gram-positive bacterial species by favorable magnetic nanocomposites from samples of different types (Scheme 1). Our novel design of furry NSs includes three steps, i.e., multi-conjugation, aggregation, and magnetic separation, to supply many characteristics as following:

(i) VCM is able to form a strong five-point hydrogen bonding with terminal groups of the cell wall structure of bacterium [17];

(ii) Furry NSs have more rapid association kinetics with bacterial cells than direct AMVCM NSs; thus, incubation times can be considerably shortened;

(iii) The "furry" ligands can be easily fabricated and modified with MNSs, thereby improving the loading capacity of VCM on NSs and dispersibility in solutions and working as a vehicle-tracking building (VTB) for the target bacteria (Gram-positive). 
The "furry action" effect of AM-PPV NSs could improve the loading capacity of VCM compared with that of direct AM-VCM NSs, which makes it more effective and accurate in the selective detection of most pathogens. The construction of furry AM-PPV NSs is schematically shown in Scheme 2, and the furry AM-PPV NSs were fabricated based on the following:

(i) The activation of the carboxylate group of VCM by EDC/NHS, and amine-PEGcarboxymethyl was coordinated to VCM to form VCM-PEG;

(ii) The immobilization of PLO through the carboxylate group on the amine-terminated MNSs to create AM-PLO through carbodiimide chemistry;

(iii) The terminal - $\mathrm{COOH}$ (carboxylate group) of the VCM-PEG molecule was bonded with $-\mathrm{NH}_{2}$ (amino group) of AM-PLO, forming furry AM-PPV NSs.

\subsection{Characterization of the Structural Features of Furry NSs}

The FE-SEM images of AM-NSs are presented at low (Figure 1A) and high (Figure 1B) magnifications. The FE-SEM micrographs provided a clear evidence of the well-controlled morphology of AM NSs, with an average particle size of $56 \mathrm{~nm}$. The image also showed the connection and overlapping of the NSs. The STEM images showed the surfaces of the AM and furry AM-PPV NSs (Figure 1C,D); it was relatively rough in AM-PPV NSs with an approximately size of $12.4 \mathrm{~nm}$ and contained an additional hydrodynamic layer of PLO/PEG/VCM, which provided additional stability in suspensions [38]. From Figure 1C, we can see that AM was heavily surrounded by the furriness from PLO/PEG/VCM. This improved the rapid separation with the help of a magnetic separator in only $15 \mathrm{~min}$, through this furriness that was combined with the D-Ala-D-Ala on the surface of Gram-positive bacterial cell membranes by a five-point hydrogen bonding.

The WA-XRD (Wide Angle X-Ray Diffraction) patterns for the fabricated magnetic NSs were scanned within the $2 \theta$ range of $10^{\circ}-80^{\circ}$. The characteristic peaks for $\mathrm{Fe}_{3} \mathrm{O}_{4}$ present in six diffraction angles of $2 \theta=30.3^{\circ}, 35.6^{\circ}, 43.3^{\circ}, 53.6^{\circ}, 57.3^{\circ}$, and $62.9^{\circ}$ were obtained in all tested materials (Figure 1E). These peaks were characterized as (220), (311), (400), (422), (511), and (440), respectively, which agrees totally with JCPDS card: 019-0629. The WA-XRD results revealed that magnetic NSs existed in all tested materials. Hence, AM, AM-PLO, and AM-PPV NSs possessed magnetism, so they could be directly removed from the water by a strong magnet easily [35].

Figure 2A confirms the successful conjugation between PEG and VCM, where the peak of VCM $(20 \mu \mathrm{g} / \mathrm{mL})$ was presented with a slight offset, which indicated the successful conjugation of VCM with PEG. PLO with an amine group in each repeat unit was formed to raise the capacity of concentration of VCM and upgrade the capture of the target bacterial cells efficacy. The absorption peak of AM-PPV furriness exhibited a high shift compared with that of VCM (Figure 2B), confirming a successful conjugation. These results confirmed the high loadings of VCM on the AM, forming AM-PPV NSs [39]. The successful synthesis of furry NSs also depended on the VCM loading quantity.

The VCM concentration was estimated to be $72.2 \mu \mathrm{g} / \mathrm{mL}$ of AM-PPV NSs based on the UV spectrometric method (Figure 3). This high loading of VCM on the AM-PLO NSs increased the selectivity capture efficiency of AM-PPV NSs for the target Gram-positive bacterial species, where high VCM loadings contributed to a multivalent interaction between the NSs and the terminal (D-alanyl-D-alanine) of the Gram-positive bacterial cell membrane through a five-point hydrogen bonding, as shown in Scheme 1. 

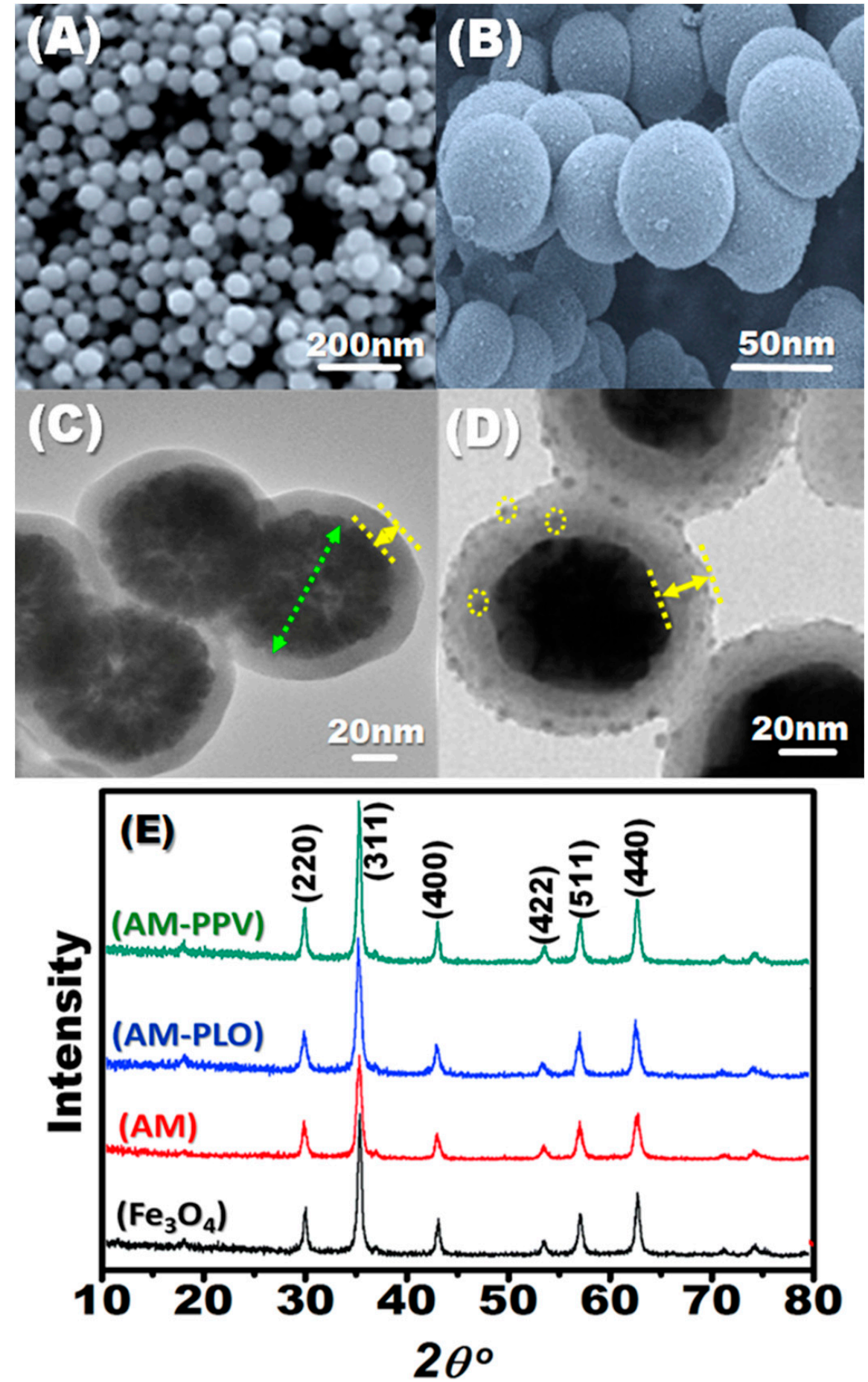

Figure 1. Field-emission scanning electron microscopy (FE-SEM) images with low (A) and high (B) magnifications of amino magnetic nanospheres (AM-NSs). High-magnification STEM images of AM-NSs (C) and AM coated with PLO/PEG/VCM (AM-PPV) NSs (D). (E) WA-XRD spectra of magnetic NSs $\left(\mathrm{Fe}_{3} \mathrm{O}_{4}\right)$, AM-NSs, AM-PLO, and AM-PPV NSs. 

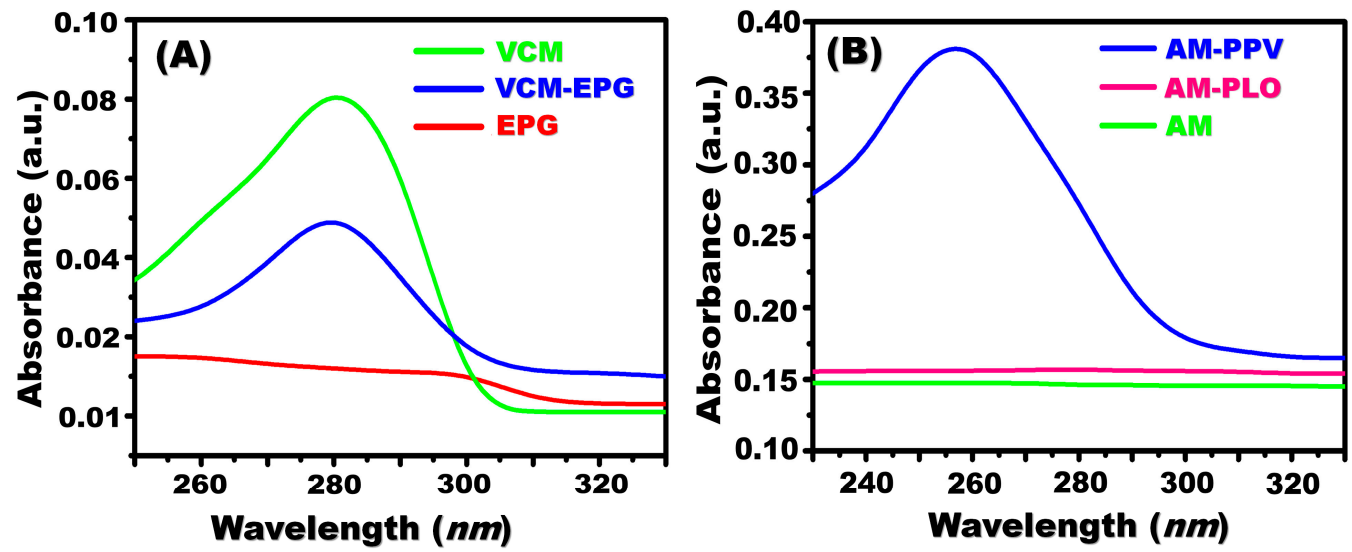

Figure 2. (A) UV-VIS absorption spectra of $20 \mu \mathrm{g} / \mathrm{mL}$ of VCM, amine-PEG-carboxymethyl, and VCMPEG; (B) UV-VIS absorption spectra of $20 \mu \mathrm{g} / \mathrm{mL}$ of AM-NSs, AM-PLO, and furry AM-PPV NSs.
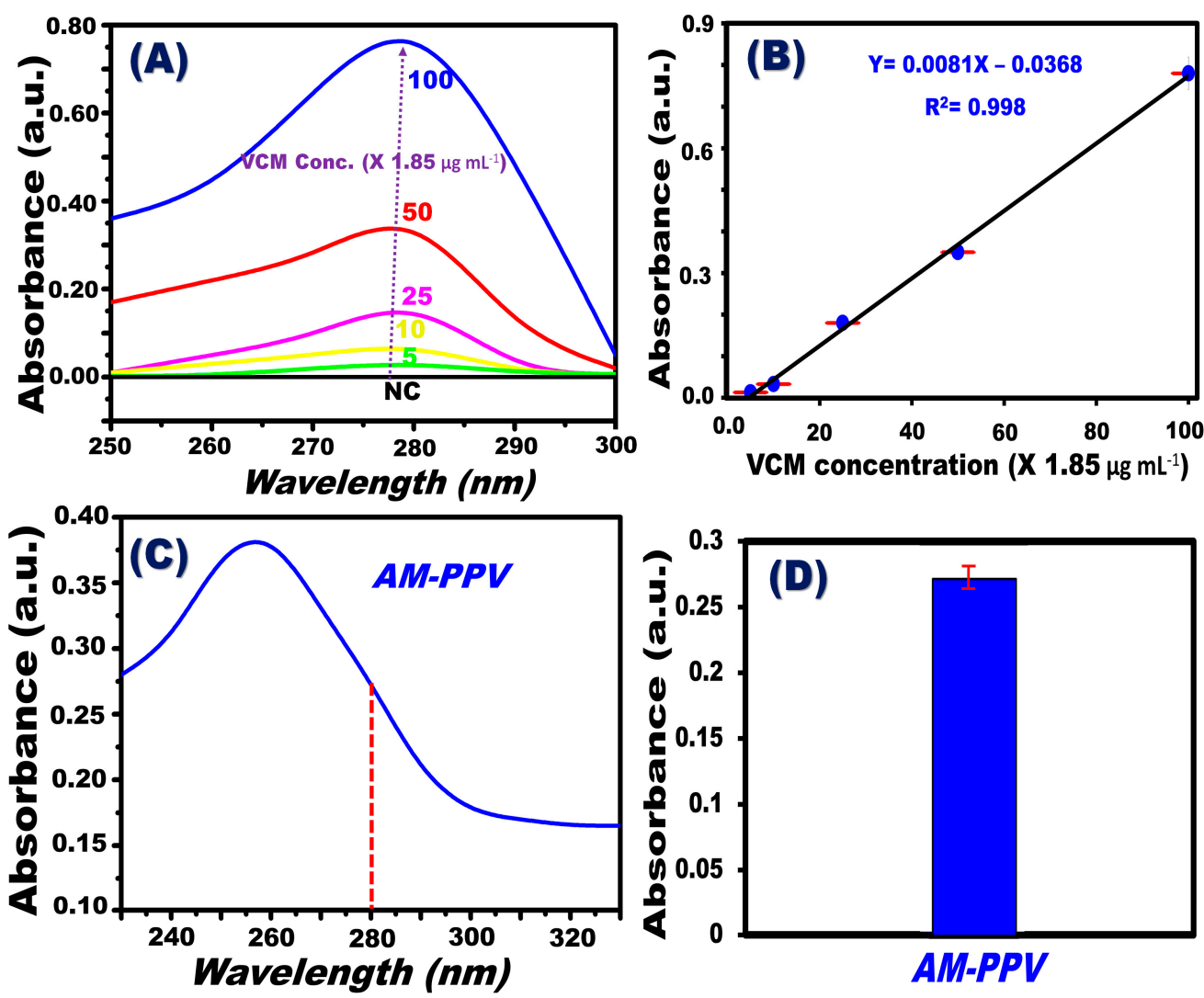

Figure 3. Determination of the VCM loading on AM-PPV NSs: (A,B) calibration curves of VCM at $280 \mathrm{~nm}$. The concentration ranged from 9.25 to $185 \mu \mathrm{g} / \mathrm{mL}$; (C) UV-VIS absorption spectrum of AM-PPV NSs; and (D) statistical results of (C) at $280 \mathrm{~nm}$.

\subsection{Functional Analysis of Furry AM-PPV NSs}

The function of the NSs is a foundation of success that affects the performance of furriness-like enrichment AM-PPV NSs. The capture capacity of AM-PPV NSs for B. cereus was spotted through TEM and SEM analyses. As shown in Figure 4A, B. cereus was heavily surrounded by the furry AM-PPV NSs. The pathogenic bacterium was rapidly and easily separated using a magnetic separator within 15 min only. These findings demonstrated the capture ability of furry AM-PPV NSs for B. cereus as a model of Gram-positive bacteria, where all Gram-positive bacterial species had the same structure of the outer cell wall, which reacted with our NSs. Therefore, they will give the same results with our synthesized 
NSs and can easily separate all Gram-positive bacterial species from mixed clinical and environmental samples for rapid diagnosis.

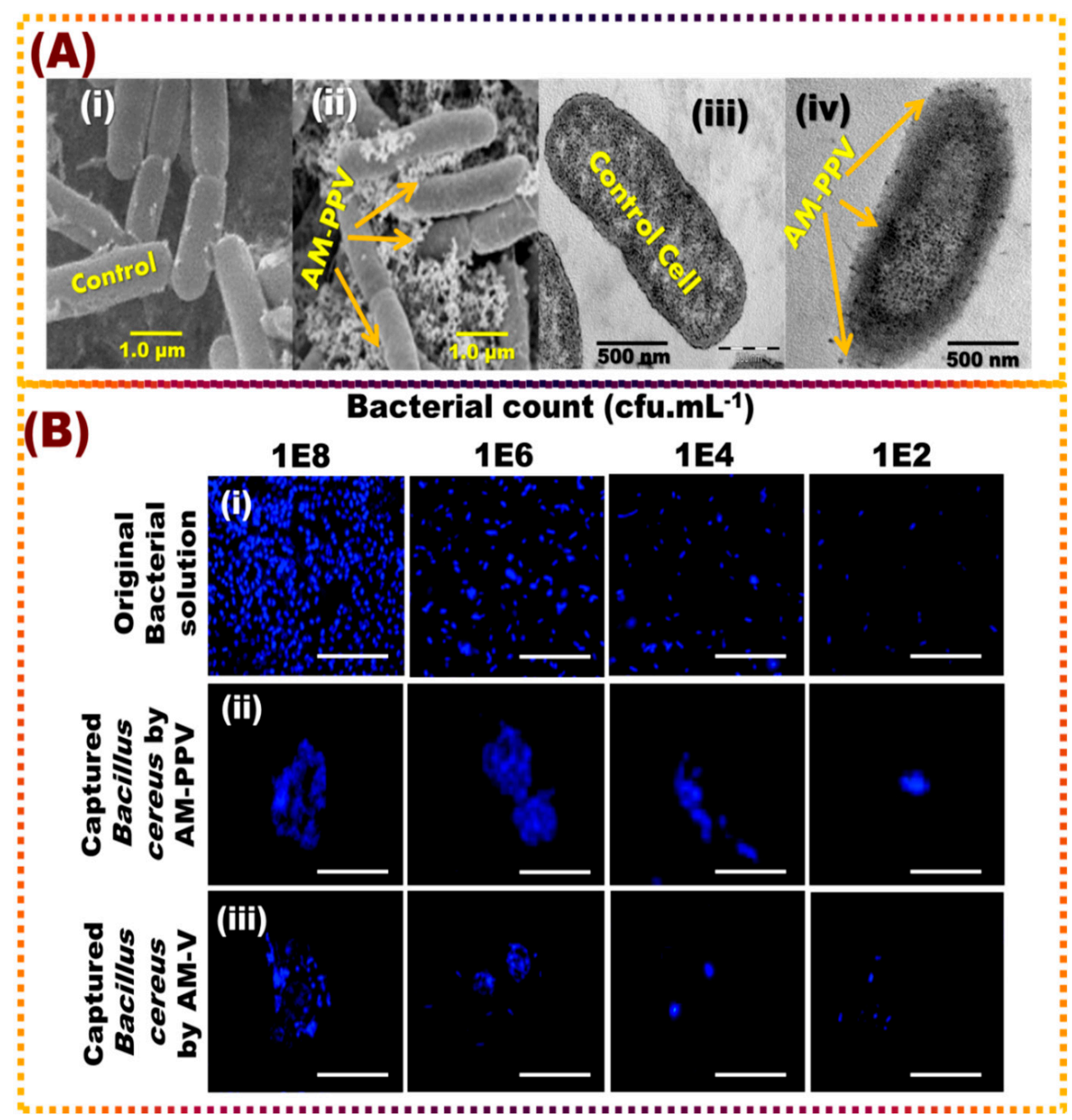

Figure 4. (A) SEM micrographs of the control (i) and the captured Bacillus cereus (B. cereus) which was conjugated with AM-PPV NSs (ii) and TEM micrographs of the B. cereus control (iii) and the captured B. cereus (iv) showing the attached AM-PPV NSs on the bacterial cell membrane; (B) fluorescence images of the captured B. cereus bacteria by furry AM-PPV NSs and direct AM-VCM. The concentrations of $B$. cereus stained by fluorescence dye ranged from $1 \times 10^{2}$ to $1 \times 10^{8} \mathrm{CFU} / \mathrm{mL}$. Scale bars: $50 \mu \mathrm{m}$.

\subsection{Capture Efficiency of Furry Magnetic NSs}

A comparative experiment of AM-PPV NSs and direct VCM conjugated to amino magnetic NSs (AM-VCM) was conducted to evaluate the capture performance of the furry NSs for B. cereus. Bacteria with different concentrations of ranging from $1 \times 10^{2}$ to $1 \times 10^{8} \mathrm{CFU} / \mathrm{mL}$ were stained by Hoechst 33258, a blue fluorescent dye that tended to interact with AT-rich DNA in cells and then were observed by fluorescent microscopy, to directly visualize the capture results. In Figure $4 B$, lane a shows the stained $B$. cereus in the original solution, whereas lane b presents the conjugates of AM-PPV NSs and B. cereus. The fluorescent images clearly indicated the binding of AM-PPV NSs to B. cereus. For all experiment groups, the fluorescence intensities increased with the increasing $B$. cereus concentration. Compared with the original solution (lane a), lane b displayed stronger fluorescence intensities, especially at high concentrations, indicating the high capture efficiency of the furry NSs for the target bacterium due to the presence of PLO furriness 
surrounding the AM-NSs, which provided great opportunities for a high load of VCM and helped in the strong capture of the target bacteria.

\subsection{The Trapping Capability of the AM-PPV NSs toward Pathogens against AM-VCM}

The trapping capability was investigated through the culturing of the remaining bacterial cells in water after the magnetic removals of both AM-PPV NSs and AM-VCM on agar plates. Figure 5A shows that the count of the left bacteria with AM-VCM NSs (Figure 5A(b1-b4)) was more than that of furry AM-PPV NSs (Figure 5A(c1-c4)).

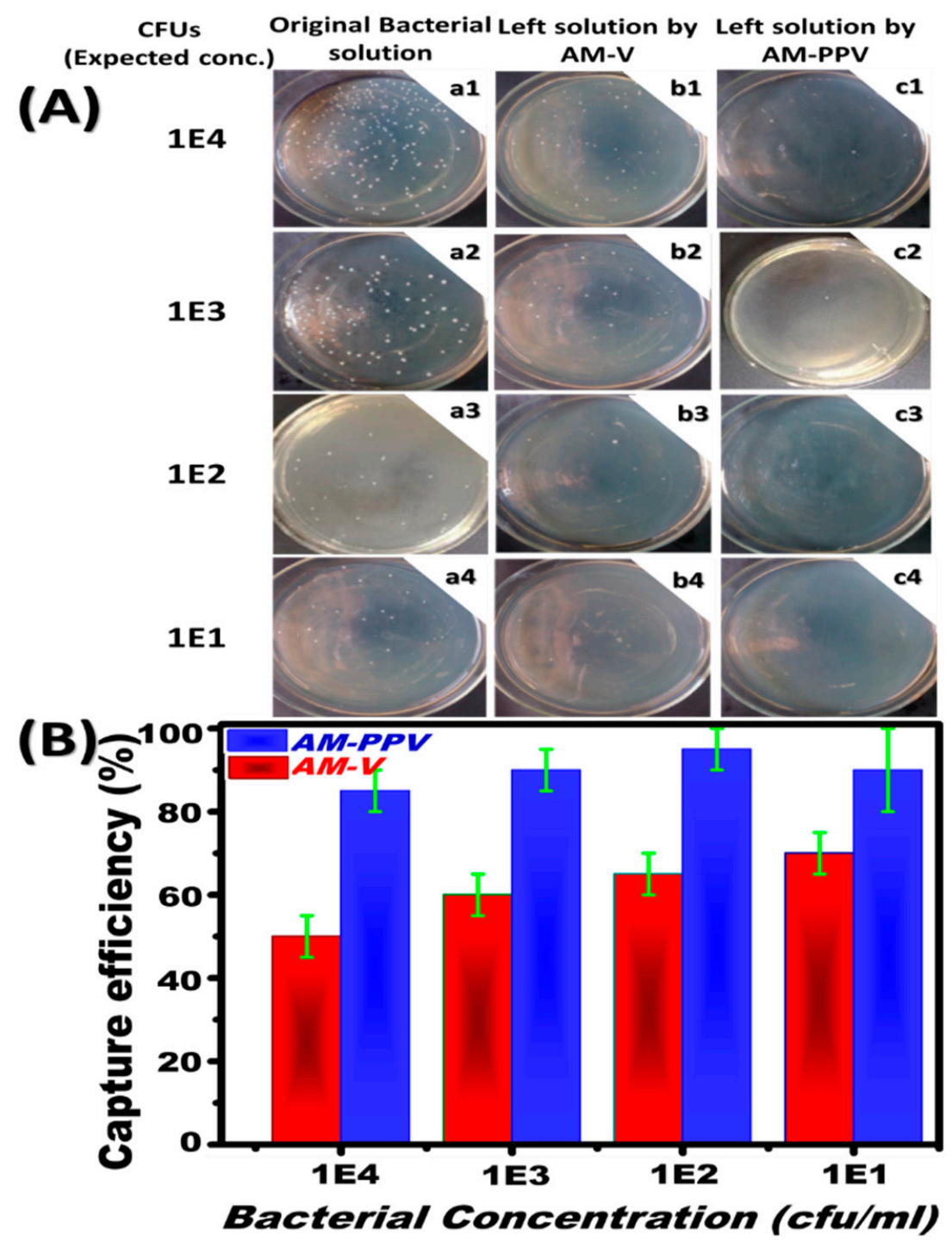

Figure 5. Comparison of the capture capabilities of amino magnetic $\mathrm{Fe}_{3} \mathrm{O}_{4} / \mathrm{VCM}$ NSs (AM-VCM) and furry AM-PPV NS evaluation by classical culture methods: (A) the photos of the plate culture presenting the colony numbers of original bacterial concentrations ranging from $1 \times 10^{4}$ to $10 \mathrm{CFU} / \mathrm{mL}$ (a1-a4); the photos of the bacteria remaining after the conjugation and magnetic separation removals for AM-VCM NSs (b1-b4) and AM-PPV NSs (c1-c4) with B. cereus, respectively; and (B) the statistical results. Data are mean \pm standard deviation ( $\mathrm{N}=3$ for all groups).

The data in Figure 5B indicated that at the $10^{2} \mathrm{CFU} / \mathrm{mL}$ concentration, the capture capacity percentage of the furry AM-PPV NSs was significantly higher $(95 \% \pm 5 \%)$ than that of the AM-VCM $(65 \% \pm 5 \%)$; moreover, at an ultralow concentration $(10 \mathrm{CFU} / \mathrm{mL})$, the capture capacity percentage of the AM-PPV NSs was $90 \% \pm 10 \%$ and the capture capacity percentage of AM-VCM NSs reached only 70\% $\pm 5 \%$. However, the capture efficiencies at the bacterial concentration of $10^{3} \mathrm{CFU} / \mathrm{mL}$ were $60 \% \pm 5 \%$ and $90 \% \pm 5 \%$, while at 
$1 \times 10^{4} \mathrm{CFU} / \mathrm{mL}$ the capture efficiencies recorded were $50 \% \pm 5 \%$ and $85 \% \pm 5 \%$ for AM-VCM and AM-PPV NSs, respectively (Table 1). Consistent with these findings, furry NSs worked as efficient nanocarriers for high-loading VCM concentrations, which supports the dissociation constant and exhibits an enhanced affinity for bacteria, resulting in a higher capture efficiency [40].

Table 1. Comparison between the efficiencies of AM-VCM and AM-PPV NSs for capturing B. cereus bacteria. (Data are means \pm standard deviation. $\mathrm{N}=3$ for all groups.)

\begin{tabular}{ccc}
\hline \multirow{2}{*}{$\begin{array}{c}\text { Bacterial Concentration } \\
\text { (CFU/mL) }\end{array}$} & \multicolumn{2}{c}{ Capture Efficiency (\%) } \\
\cline { 2 - 3 } & AM-VCM NSs & AM-PPV NSs \\
\hline $1 \times 10^{-4}$ & $50 \pm 5$ & $85 \pm 5$ \\
$1 \times 10^{-3}$ & $60 \pm 5$ & $90 \pm 5$ \\
$1 \times 10^{-2}$ & $65 \pm 5$ & $95 \pm 5$ \\
10 & $70 \pm 5$ & $90 \pm 10$ \\
\hline
\end{tabular}

\subsection{Selectivity of Furry AM-PPV NSs for Gram-Positive Bacteria in the Mixed Sample}

The mixed water sample containing G-positive (B. cereus) and G-negative (P. aeruginosa, K. pneumoniae, and E. coli) bacteria was used for testing the selectivity of AM-PPV NSs, where furry NSs were applied for the mixed sample to separate B. cereus (Gram-positive) bacteria from the sample by a magnet, when the remaining bacterial species in the samples were cultivated on nutrient agar plates to demonstrate the specificity of AM-PPV NSs. The bacterial growths only detected on the plates were for E. coli, K. pneumoniae, and P. aeruginosa (Gram-negative), whereas no growth of B. cereus was observed on the plates as shown in Scheme 3. These results confirmed that through the subsequent specificity of furry AM-PPV NSs for the detection of Gram-positive bacterial species, the furry AM-PPV NSs can be applied to complex clinical and environmental bacterial samples for the detection of bacterial contamination and rapid separation diagnosis [17].

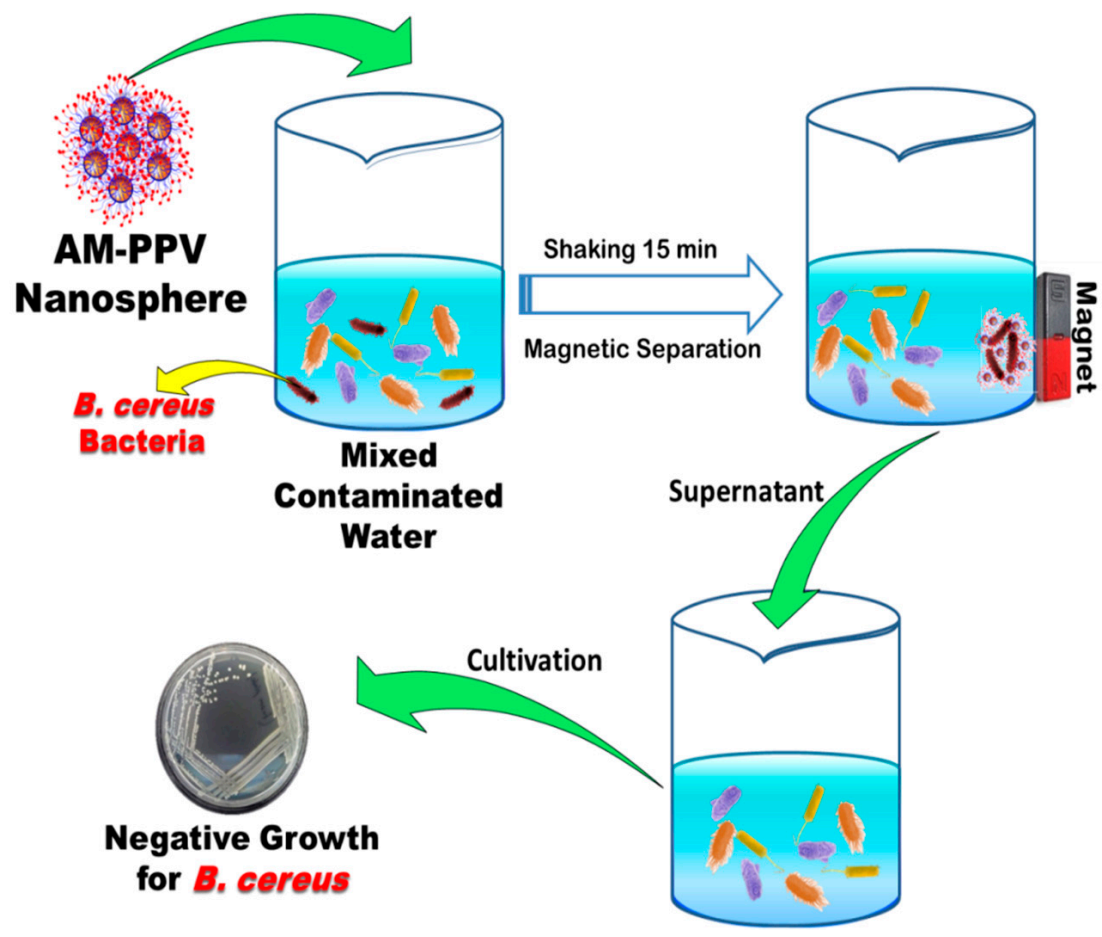

Scheme 3. Selectivity of furry AM-PPV NSs for Gram-positive bacteria in the mixed contaminated water sample containing B. cereus (Gram-positive), Escherichia coli, Klebsiella pneumoniae, and Pseudomonas aeruginosa (Gram-negative). 


\section{Conclusions}

We successfully constructed novel furry magnetic high-loading VCM NSs with a high selectivity for rapid pathogen detection. Our designed AM-PPV NSs increased the loading of VCM, upgraded the capture capacity of bacterial cells and worked as a VTB for the target Gram-positive bacterial species, where PLO with a repeat amino group formed the corona of elastic cilia terminated with VCM molecules. VCM was able to form a strong five-point hydrogen bonding with terminal groups of the cell wall structure of the bacterium. Thus, the modified AM-PPV NSs obtained more dispersibility and biocompatibility and can be used in complex environmental and clinical samples. The use of AM-PPV NSs were more rapid than other previous methods, where $>90 \%$ of B. cereus bacterial cells could be efficiently captured within only 15 min with a very low detection limit reaching an ultralow concentration of $10 \mathrm{CFU} / \mathrm{mL}$. These properties and performance make AM-PPV NSs a potentially useful approach to the rapid diagnosis of Gram-positive bacterial pathogens in clinical and environmental samples.

Author Contributions: Conceptualization, A.M.A., M.A.S. and S.A.E.-S.; methodology, A.M.A., M.A.S., B.M. and A.T.; software, A.M.A., M.A.S. and M.S.S.; validation, A.M.A., M.A.S., M.S.S., B.M., A.T. and S.A.E.-S.; formal analysis, A.M.A., M.A.S. and A.T.; investigation, A.M.A., M.A.S., B.M., A.T. and S.A.E.-S.; data curation, A.M.A., M.A.S., B.M. and A.T.; writing-original draft preparation, A.M.A., M.A.S. and S.A.E.-S.; writing-review and editing, A.M.A., M.A.S., M.S.S., B.M., A.T. and S.A.E.-S.; supervision, S.A.E.-S. All authors have read and agreed to the published version of the manuscript.

Funding: This research received no external funding.

Data Availability Statement: Data Availability Statement: Data can be available upon request from the authors.

Acknowledgments: This work was supported by the Center for Functional Materials, National Institute for Materials Science (NIMS), Japan, and the Environmental Research Department, Theodor Bilharz Research Institute, Egypt.

Conflicts of Interest: The authors declare no conflict of interest.

\section{References}

1. Ma, X.; Ding, W.; Wang, C.; Wu, H.; Tian, X.; Lyu, M.; Wang, S. DNAzyme biosensors for the detection of pathogenic bacteria. Sens. Actuators B Chem. 2021, 331, 129422. [CrossRef]

2. Alhogail, S.; Suaifan, G.A.; Zourob, M. Rapid colorimetric sensing platform for the detection of Listeria monocytogenes foodborne pathogen. Biosens. Bioelectron. 2016, 86, 1061-1066. [CrossRef] [PubMed]

3. Jovanovic, J.; Ornelis, V.F.M.; Madder, A.; Rajkovic, A. Bacillus cereus food intoxication and toxicoinfection. Compr. Rev. Food Sci. Food Safety 2021, 20, 3719-3761. [CrossRef] [PubMed]

4. Farooq, U.; Ullah, M.W.; Yang, Q.; Aziza, A.; Xu, J.; Zhou, L.; Wang, S. High-density phage particles immobilization in surfacemodified bacterial cellulose for ultra-sensitive and selective electrochemical detection of Staphylococcus aureus. Biosens. Bioelectron. 2020, 157, 112163. [CrossRef] [PubMed]

5. Yang, S.; Zuo, C.; Dai, L.; Guo, Y.; Xie, G. Applying CRISPR-Cas12a as a signal amplifier to construct biosensors for non-DNA targets in ultralow concentrations. ACS Sens. 2020, 5, 970-977.

6. Capobianco, J.A.; Armstrong, C.M.; Lee, J.; Gehring, A.G. Detection of pathogenic bacteria in large volume food samples using an enzyme-linked immunoelectrochemical biosensor. Food Control 2021, 119, 10745. [CrossRef]

7. Law, J.W.; Ab Mutalib, N.S.; Chan, K.G.; Lee, L.H. Rapid methods for the detection of foodborne bacterial pathogens: Principles, applications, advantages and limitations. Front. Microbiol. 2014, 5, 770-788. [CrossRef]

8. Cheng, D.; Yu, M.; Fu, F.; Han, W.; Li, G.; Xie, J.; Song, Y.; Swihart, M.T.; Song, E. Dual recognition strategy for specific and sensitive detection of bacteria using aptamer-coated magnetic beads and antibiotic-capped gold nanoclusters. Anal. Chem. 2016, 88, 820-825. [CrossRef]

9. Shenashen, M.A.; Derbalah, A.; Hamza, A.; Mohamed, A.; El Safty, S.A. Antifungal activity of fabricated mesoporous alumina nanoparticles against rot root disease of tomato caused by Fusarium oxysporium. Pest Manag. Sci. 2017, 73, 1121-1126. [CrossRef]

10. Azzam, A.M.; Shenashen, M.A.; Selim, M.M.; Alamoudi, A.S.; El-Safty, S.A. Hexagonal $\mathrm{Mg}(\mathrm{OH})_{2}$ nanosheets as antibacterial agent for treating contaminated water sources. ChemistrySelect 2017, 2, 11431-11437. [CrossRef] 
11. Emran, M.Y.; Akhtar, N.; Mekawy, M.; Shenashen, M.A.; El-Sewify, I.M.; Faheem, A.; El-Safty, S.A. Broccoli-shaped biosensor hierarchy for electrochemical screening of noradrenaline in living cells. Biosens. Bioelectron. 2018, 100, 122-131. [CrossRef] [PubMed]

12. Emran, M.Y.; Shenashen, M.A.; Mekawy, M.; Azzam, A.M.; Akhtar, N.; Gomaa, H.; Selim, M.M.; Faheem, A.; El-Safty, S.A Ultrasensitive in-vitro monitoring of monoamine neurotransmitters from dopaminergic cells. Sens. Actuators B Chem. 2018, 259, 114-124. [CrossRef]

13. Li, X.; Shenashen, M.A.; Wang, X.; Ito, A.; Taniguchi, A.; EI-Safty, S.A. Mesoporous Caged- $\gamma$-AlOOH-Double-Stranded RNA analog complexes for cancer immunotherapy. Adv. Biosyst. 2018, 2, 1700114. [CrossRef]

14. Emran, M.Y.; Khalifa, H.; Gomaa, H.; Shenashen, M.A.; Akhtar, N.; Mekawy, M.; Faheem, A.; El-Safty, S.A. Hierarchical C-N doped $\mathrm{NiO}$ with dual-head echinop flowers for ultrasensitive monitoring of epinephrine in human blood serum. Microchim. Acta 2017, 184, 4553-4562. [CrossRef]

15. Akhtar, N.; El-Safty, S.A.; Abdelsalam, M.E.; Shenashen, M.A.; Kawarada, H. Radially oriented nanostrand electrodes to boost glucose sensing in mammalian blood. Biosens. Bioelectron. 2016, 77, 656-665. [CrossRef]

16. Wang, Y.; Ju, Z.; Cao, B.; Gao, X.; Zhu, Y.; Qiu, P.; Xu, H.; Pan, P.; Bao, H.; Wang, L. Ultrasensitive rapid detection of human serum antibody biomarkers by biomarker-capturing viral nanofibers. ACS Nano 2015, 9, 4475-4483. [CrossRef]

17. Yang, S.; Ouyang, H.; Su, X.; Gao, H.; Kong, W.; Wang, M.; Shu, Q.; Fu, Z. Dualrecognition detection of Staphylococcus aureus using vancomycin-functionalized magnetic beads as concentration carriers. Biosens. Bioelectron. 2016, 78, 174-180. [CrossRef]

18. Emran, M.Y.; Shenashen, M.A.; Abdelwahab, A.A.; Abdelmottaleb, M.; Khairy, M.; El-Safty, S.A. Nanohexagonal Fe ${ }_{2} \mathrm{O}_{3}$ electrode for one-step selective monitoring of dopamine and uric acid in biological samples. Electrocatalysis 2018, 9, 514-525. [CrossRef]

19. Selim, M.S.; Elmarakbi, A.; Azzam, A.M.; Shenashen, M.A.; EL-Saeed, A.M.; El-Safty, S.A. Eco-friendly design of superhydrophobic nano-magnetite/silicone composites for marine foul-release paints. Prog. Org. Coat. 2018, 116, 21-34. [CrossRef]

20. Raval, Y.S.; Stone, R.; Fellows, B.; Qi, B.; Huang, G.; Mefford, O.T.; Tzeng, T.R.J. Synthesis and application of glycoconjugatefunctionalized magnetic nanoparticles as potent anti-adhesion agents for reducing enterotoxigenic Escherichia coli infections. Nanoscale 2015, 7, 8326-8331. [CrossRef]

21. Jo, S.M.; Lee, J.J.; Heu, W.; Kim, H.S. Nanotentacle-structured magnetic particles for efficient capture of circulating tumor cells. Small 2015, 11, 1975-1982. [CrossRef] [PubMed]

22. Kuo, F.-Y.; Lin, W.-L.; Chen, Y.-C. Affinity capture using peptide-functionalized magnetic nanoparticles to target Staphylococcus aureus. Nanoscale 2016, 8, 9217-9225. [CrossRef] [PubMed]

23. Bruno, J.G. Application of DNA aptamers and quantum dots to lateral flow test strips for detection of foodborne pathogens with improved sensitivity versus colloidal gold. Pathogens 2014, 3, 341-355. [CrossRef]

24. Gu, H.; Ho, P.; Tsang, K.W.T.; Wang, L.; Xu, B. Using biofunctional magnetic nanoparticles to capture vancomycin-resistant Enterococci and other Gram-positive bacteria at ultralow concentration. J. Am. Chem. Soc. 2003, 125, 15702-15703. [CrossRef] [PubMed]

25. Luciani, M.; Di Febo, T.; Zilli, K.; Di Giannatale, E.; Armillotta, G.; Manna, L.; Minelli, F.; Tittarelli, M.; Caprioli, A. Rapid detection and isolation of Escherichia coli O104:H4 from milk using monoclonal antibody-coated magnetic beads. Front. Microbiol. 2016, 7 , 942-951. [CrossRef] [PubMed]

26. Poshtiban, S.; Javed, M.A.; Arutyunov, D.; Singh, A.; Banting, G.; Szymanski, C.M.; Evoy, S. Phage receptor binding protein-based magnetic enrichment method as an aid for real time PCR detection of foodborne bacteria. Analyst 2013, 138, 5619-5626. [CrossRef] [PubMed]

27. Li, Y.; Yu, H.; Qian, Y.; Hu, J.; Liu, S. Amphiphilic star copolymer-based bimodal fluorogenic/magnetic resonance probes for concomitant bacteria detection and inhibition. Adv. Mater. 2014, 26, 6734-6741. [CrossRef]

28. Lee, J.-G.; Sagui, C.; Roland, C. First Principles Investigation of Vancomycin and Teicoplanin Binding to Bacterial Cell Wall Termini. J. Am. Chem. Soc. 2004, 126, 8384-8385. [CrossRef]

29. Bottone, E.J. Bacillus cereus, a volatile human pathogen. Clin. Microbiol. Rev. 2010, 23, 382-398. [CrossRef]

30. Hui, C.; Shen, C.; Tian, J.; Bao, L.; Ding, H.; Li, C.; Tian, Y.; Shiab, X.; Gao, H. Core-shell Fe ${ }_{3} \mathrm{O}_{4} @ S i O 2$ nanoparticles synthesized with well-dispersed hydrophilic $\mathrm{Fe}_{3} \mathrm{O}_{4}$ seeds. Nanoscale 2011, 3, 701-705. [CrossRef]

31. Safavieh, M.; Ahmed, M.U.; Tolba, M.; Zourob, M. Microfluidic electrochemical assay for rapid detection and quantification of Escherichia coli. Biosens. Bioelectron. 2012, 31, 523-528. [CrossRef] [PubMed]

32. Ma, X.; Song, L.; Zhou, N.; Wang, Z. A novel aptasensor for the colorimetric detection of S. typhimurium based on gold nanoparticles. Int. J. Food Microbiol. 2017, 245, 1-5. [CrossRef] [PubMed]

33. Cesewski, E.; Johnson, B.N. Electrochemical biosensors for pathogen detection. Biosens. Bioelectron. 2020, 159, 112214. [CrossRef]

34. Chen, Y.; Qian, C.; Liu, C.; Shen, H.; Wang, Z.; Ping, J.; Wu, J.; Chen, H. Nucleic acid amplification free biosensors for pathogen detection. Biosens. Bioelectron. 2020, 153, 112049. [CrossRef] [PubMed]

35. Chen, Q.; Lin, J.; Gan, C.; Wang, Y.; Wang, D.; Xiong, Y.; Lai, W.; Li, Y.; Wang, M. A sensitive impedance biosensor based on immunomagnetic separation and urease catalysis for rapid detection of Listeria monocytogenes using an immobilization-free interdigitated array microelectrode. Biosens. Bioelectron. 2015, 74, 504-511. [CrossRef] [PubMed]

36. Huang, Y.; Wang, Y.; Wang, Y.; Pan, Q.; Ding, X.; Xu, K.; Li, N.; Wen, Q. Ionic liquid-coated Fe ${ }_{3} \mathrm{O}_{4} / \mathrm{APTES}_{\text {graphene oxide }}$ nanocomposites: Synthesis, characterization and evaluation in protein extraction processes. RSC Adv. 2016, 6, 5718-5728. [CrossRef] 
37. Jin, Y.; Liu, F.; Shan, C.; Tong, M.; Hou, Y. Efficient bacterial capture with amino acid modified magnetic nanoparticles. Water Res. 2014, 50, 124-134. [CrossRef] [PubMed]

38. Larsson, M.; Hill, A.; Duffy, J. Suspension stability; why particle size, zeta potential and rheology are important. Annu. Trans. Nord. Rheol. Soc. 2012, 20, 209-214.

39. Rostova, E.; Ben-Adiba, C.; Dietler, G.; Sekatskii, S.K. Kinetics of antibody binding to membranes of living bacteria measured by a photonic crystal-based biosensor. Biosensors 2016, 6, 52-60. [CrossRef]

40. Kell, A.J.; Stewart, G.; Ryan, S.; Peytavi, R.; Boissinot, M.; Huletsky, A.; Bergeron, M.G.; Simard, B. Vancomycin-modified nanoparticles for efficient targeting and preconcentration of gram-positive and gram-negative bacteria. ACS Nano 2008, 2, 1777-1788. [CrossRef] 